\title{
The Making of Indonesian Education: An Overview on Empowering Indonesian Teachers
}

\author{
Teuku Zulfikar \\ Monash University
}

\begin{abstract}
Education is one of the fundamental priorities of nation building. For this reason, the Indonesian government continuously seeks to improve the quality of its education. Empowering education can be done using many strategies, such as reforming school curricula or school systems or both. This article approaches the improvement of Indonesian education from a different angle, by considering teachers and the teaching profession. Before proposing an agenda for improving teachers, the article considers two main problems of Indonesian teachers: the practice of teacher-centred classroom pedagogy; and the emphasis on rote learning in the classroom. In response to these phenomena, this article suggests two main factors responsible for the persistence of such teaching styles: institutional cultures and the nature of assessment systems in Indonesian schools. This article has three recommendations to help Indonesian teachers improve. However, the author is aware that the agendas for improvement are complex and institutional reforms are needed; for example, the reform of teacher recruitment; teacher evaluation and also the reform of assessment systems. This article includes a discussion of what makes for a good teacher, which will help Indonesian teachers to gain an insight to their profession, and a discussion of the changes that could be made to enable the quality of teaching to improve.
\end{abstract}

\section{Introduction}

Teaching is indeed a complex profession; it is also a challenging one in which teachers have to meet various social and intellectual demands. Successful teachers are not simply responsible for transferring knowledge, they must transfer it effectively and successfully, and for that reason alone, they should organise classrooms, implement effective classroom pedagogy and work cooperatively with a diversity of students and colleagues (McCaughtry, Cothran, Kulinna, Martin and Faust, 2005). Despite the significant role of teachers in the classroom, 
many Indonesian teachers have been found to lack teaching competence (Azra, 2002). This has been observed by Bjork (2005) and ascribed to the long tradition of teacher-centred teaching and rote learning in the Indonesian classroom.

Teacher-centred class instruction is deeply embedded in Indonesian school settings; this type of instruction has become a part in the Indonesian school culture (Azra, 2002; Bjork, 2005; Buchori, 2001). There is a consensus that such an instruction method provides little room for students to be creative and expressive (Kohl, 1994; Shor, 1992; Wolk, 1998). Teacher-centred class instruction is said to be undemocratic because it fails to take into account students' learning dynamics and ignores students' contributions in the classroom (Wolk, 1998). In addition to teacher-centred instruction, rote learning is still common in Indonesian schools (Bjork, 2005). There is no suggestion that rote learning should be totally avoided in the Indonesian context because this type of instruction has some advantages for students; for example, rote learning of historical dates. However, excessive use of rote learning means there is less emphasis on more student-centred aspects of learning, such as the critical analysis of history itself. Rote learning plays a large part in Indonesians schools because it is believed to be able to transfer knowledge to students through memorisation. With rote learning, students are judged to be successful when they are able to memorise lessons or topics within their subjects. Even though education practitioners in Indonesia criticise the use of excessive rote learning and attempt to eliminate it (Azra, 2002), such methods prevail.

Because teacher-centred and rote learning have become commonplace in the Indonesian school culture (Azra, 2002; Bjork, 2005; Darmaningtyas, 2004), this article aims at exploring factors leading to the long prevalence of such instruction methods in Indonesian schools; it considers how to minimise the problem; and gives some thought to the characteristics of successful teachers. This article begins by looking at factors causing such classroom pedagogy. This first section identifies two underlying factors to teacher-centred and rote learning: institutional cultures and the assessment system. The second section of this article 
deals with some suggestions to minimise teacher-centred and rote learning systems. The third section discusses the necessary attributes of successful teachers, attributes that Indonesian teachers should emulate if they are to be successful in the teaching profession. I will conclude with a discussion of the applicability of these proposed solutions to the Indonesian education system.

\section{Teacher-centred and Rote Learning: Cultures of the Indonesian Classroom}

\section{Institutional Culture}

Discussions of the negative effects of institutional cultures on Indonesian teachers will be mainly based on the work of Christopher Bjork (2005), who conducted comprehensive research on the Indonesian education system. His research reveals that Indonesian teaching practices are mostly attached to institutional cultures and the education system. I define institutional cultures as systems played out within the Indonesian education system; the system of teacher recruitment (by civil service institutions); the system of teacher evaluation and promotion; and common practices of Indonesian school systems (school cultures). Bjork (2005) gives insights on factors leading to the long history of teacher-centred classroom methods and the system of rote learning in Indonesian schools. He suggests that most Indonesian teaching practices in the school setting are to fit in with the institutional culture to which the teaching profession subscribes (Bjork, 2005, p. 83). This suggests that teachers are dependent on the rules and regulations imposed on them through institutional policies (of such civil service institutions as the Ministry of National Education and the Ministry of Religious Affairs) and common practices in Indonesian schools.

Indonesian education is a highly centralised and top-down system. School teachers are recruited, employed and deployed by the central government (Gardiner, 2000). Teachers recruited and employed by a government body, such as the Ministry of National Education (MONE) or the Ministry of Religious Affairs (MORA), belong to pegawai negeri 
institutions (that is, they are civil servants or government employees). As pegawai negeri, teachers are subject to and dependent on government regulations, which control their working conditions (Gardiner, 2000). For instance, teachers are obliged to fulfil the seven promises of the Republic of Indonesia's employee corps, to follow guidelines for national discipline at school, and also are expected to follow the teacher's code of conduct. During his fieldwork, Bjork (2005) observed in various official meetings, the rapat dinas, that a teachers' performance is judged on their loyalty to regulations enforced by the pegawai negeri institutions. Bjork (2005) also reveals that series of school meetings are conducted to emphasise teachers' obligation to fulfil disciplinary conditions mandated by the pegawai negeri institutions, but discussion of teaching performance has no place in the meetings.

There is little discussion of teachers' classroom practices at teachers' meetings; teaching performance is not evaluated, constructively criticised or appreciated. The only basis of evaluation is teachers' progress in transmitting and meeting the curriculum schedule, managerial issues such as organising examinations, commitment to the flag ceremony, and attending official meetings and other such bureaucratic requirements (Bjork, 2005). These conditions discourage teachers from concentrating on their teaching performance. This also suggests that, institutionally, teachers have been made powerless and their professional vision blinkered. The institutions of pegawai negeri have transformed teachers into dependent entities who follow orders, commit to the government regulations and fulfil the curriculum schedule; improving their teaching ability is not so much required (Bjork, 2005). These practices, common in the civil service, ignore the special nature of education and educational institutions: at present teachers are given few incentives to attend to their students learning attitudes and habits. Treating teachers simply as civil servants and not as professional educators will not enable them to have a rewarding career nor will it bring about the best education outcomes for the nation. Understanding how students learn and the factors that can affect their individual education needs are imperative if a teacher is to be considered successful (Marjoribanks, 1991; Wolk, 1998). 
Indonesian school cultures (common practices in Indonesian schools) also cause teachers to be rigid in their teaching schedules. Most teachers spend little time at school, arriving just minutes before they begin teaching. After lessons, most engage in chatting instead of evaluating their students' work (Bjork, 2005). Teachers are also not expected to be substitute teachers during the absence of any permanent teachers. Indonesian school cultures also do not encourage teachers to be willing to stay at school after teaching hours for consultation with students' about academic matters. In fact, in his observations, Bjork (2005) found that teachers frequently put the blame on students for their (students') academic failure. Worse, teachers are not expected by school cultures to give any thought to the causes of a student's failure. Bjork (2005) also found that meetings to discuss and consider student failure are missing from the Indonesian school contexts.

The cultures at play at the civil-service institutions give teachers neither space nor opportunities to review their classroom pedagogy. Because they are government employees, loyalty and obedience are stressed more so than their skills and ability in the classroom (Bjork, 2005); such treatment indicates that top-down power influence has yet to be eliminated from the Indonesian education system. It has been suggested by Bjork that teachers' evaluation is more concerned with teachers' ability to transfer knowledge based on the curriculum schedules rather than on evaluating their classroom pedagogy. Such an institutional culture discourages teachers from evaluating their instructional pedagogy, and thus teacher-centred classroom pedagogy remains prevalent.

\section{Systems of Assessment}

The Indonesian education system emphasises in-class examinations to assess student academic achievement. In Indonesian schools, students sit standardised and highly centralised examinations (Gardiner, 2000), in which the test questions are set centrally. These types of examination frequently use multiple choice questions; few require written essays. Examinations in class are administered to record students' academic 
achievement and as a foundation to grant the student a higher grade. In addition to administering examinations each semester, the central government also enforces national examinations at the end of Year 6, at the end of Year 9 (grade 3 of SMP or junior high school) and at the end of Year 12 (grade 3 of SMU or senior high school). Implementing the national examination (ujian nasional) is not without problems; it has attracted severe criticism from many scholars, such as Oey-Gardiner (2005) and Lie (2004), who assert that the implementation of a national examination is a poor way to measure students' academic achievement. The system of national examinations has been accused of aggravating conditions of Indonesian education because it measures students' cognitive ability only, for example, the ability to memorise certain topics of the lesson (Daud, 2009; Khalifa, 2009; Soaloon, 2009).

Because the assessment system is in-class examinations, which test students' memorisation of particular topics in the lessons, classroom pedagogy follows suit, in that teachers are trapped into employing pedagogy that stresses students' memorisation skills for success in the examinations. Indonesian teachers are left with no choice but to implement classroom pedagogy with its emphasis on rote learning. As an insider in the Indonesian education system, I am aware of these factors related to the emergence and existence of rote learning. The government is also accused of lacking commitment to evaluate the assessment system. In fact, Gardiner (2005) suggests that the Ministry of Education finds ways to ignore criticisms on the issue of national examinations. Lie (2004) also severely criticises government policy on national examinations. She contends that the enforcement of the current national examination system implies that the government is displeased with decentralising authority; that the central government intends to maintain control and authority over education management Indonesiawide (Lie, 2004).

If in-class summative assessments and national examinations remain common in the Indonesian schools, the system of rote learning will continue. In this case, Indonesian teachers are not the only ones to blame for the implementation of rote learning in Indonesian schools. 
Rote learning takes place at least for two reasons: first, teachers' lack of teaching competence, in which they do not possess sufficient pedagogical knowledge to conduct instruction and they have been denied opportunities to empower themselves by improving their teaching skills; and second, the highly centralised system of assessment.

To sum up, this section has attempted to clarify that the long tradition of teacher-centred classroom pedagogy and rote learning is a complex phenomenon. It prevails because of related factors; the system of teacher recruitment and evaluation, classroom practices common to so many Indonesian schools, the system of assessment, and teachers' lack of teaching competence; all these combine to ensure that these instructional traditions continue. Because teacher-centred and rote learning is complex, the solutions are also complex. The hierarchical structure of education should be changed, Indonesian education must be detached from a highly centralised management that administers teacher recruitment, teaching evaluation and systems of assessment. The following section deals with some insights on manipulating teachercentred classroom pedagogy and rote learning.

\section{Efforts for Improvement}

In this second section, I propose some ideas that might minimise, if not eliminate, the dependency and the strong attachment of teachers to institutional cultures and to the current education system. Three suggestions are proposed in this section: reforming the systems at the schools and the pegawai negeri institutions; implementation of appropriate teaching evaluation; and reformulation of assessment systems. These thoughts, however, are not magic words that eliminate the use of teacher-centred learning approach and system of rote learning in the Indonesian schools in no time.

\section{Institutional Reform}

Because the civil service institutions or the nature of pegawai negeri are 
assumed to affect the teacher-centred methods of instruction (discussed elsewhere), the first and most urgent matter is to detach teachers from their dependence on and deference to the policies and regulations of the central government's education authorities, that is, MORA and MONE. One possible way to make teachers more independent is by finding other methods of recruiting them. This suggestion aims at reducing teachers' dependence on institutional cultures. Currently, teachers are recruited through the pegawai negeri test. The content of this test is also problematic because the areas tested are Indonesian civic education, English as a foreign language and the Indonesian language. Although these are important subjects, they cannot be used as the foundation to judge the competence of candidates for teaching positions. The current recruitment system does not guarantee teacher quality. The test does not measure the content or pedagogical knowledge of potential teachers but instead focuses on candidates' understanding of four areas only: maths, English, civic education and the Indonesian language. This suggests that the test fails to recruit good teachers who have excellent capability in content and pedagogical knowledge. In the construction of a better teacher recruitment system, two components should be well considered.

First, the recruitment process should be decentralised to give schools the right and authority to recruit teachers who best meet their school's needs and fit their expectations. At present, teachers are recruited by the pegawai negeri institutions: the Ministry of Religious Affairs (MORA), which recruits teachers for Islamic schools; and the Ministry of National Education (MONE), which recruits teachers for general public schools. This centralised recruitment is criticised for not being able to produce teachers who suit particular school cultures and settings; the centralised recruitment also forces teachers to submit themselves to disciplinary regulations imposed by those pegawai negeri bodies (MORA and MONE).

Second, the test and recruitment procedures should be reformed. The test contents should range from civic education - if it is still considered important in contemporary Indonesia- to subject content and 
pedagogical skills. The former is knowledge of the subject matter the teacher will teach and the latter is classroom pedagogical knowledge, which is teaching skill. Good content knowledge and pedagogical ability are the most important skills for successful teachers. During recruitment, teacher candidates need to go through at least four phases: they must provide schools with their curriculum vitae, teaching portfolio and qualification documentation; there must be a series of interviews by the senior teachers and the school principal; a test of content knowledge; and a test of pedagogical knowledge through practicum tests where candidates would be scheduled to teach for some minutes in front of examiners who are senior and experienced teachers. These four phases of recruitment would enable the school committee to judge prospective teachers who might suit the school and to recruit teachers who would understand and be responsible in their teaching obligations.

Such teacher recruitment system has two benefits: first, it enables a particular school to recruit teachers who best meet their needs. Teachers who are assigned to a school through centralised recruitment would not necessarily work effectively in that particular school. Second, a decentralised teacher recruitment system would detach teachers from centralised pegawai negeri institutions and the disciplinary regulations associated with them. Teachers employed through a decentralised system of recruitment would be primarily responsible to the schools that recruit them. Finally, the most significant benefit is that teachers would not need to abide by disciplinary obligations and regulations that do not directly link to their teaching professionalism.

\section{Teaching Evaluation}

In addition to reforming teachers' recruitment system, evaluations of Indonesian teachers' classroom pedagogy should be properly and regularly implemented so that teacher-centred classroom pedagogy can be minimised and then abolished in Indonesian education systems. The school should first set the standard of good teaching because attempts to gain academic improvement should come from within the teaching workforce itself(Ingvarson and Chadbourne, 1994). Evaluating teachers 
is important; it promotes better classroom practices (McLaughlin and Pfeifer, 1988) and it holds teachers responsible for what they teach and why they choose a particular teaching approach (Ingvarson and Chadbourne, 1994).

There are at least two ways teachers can engage in teaching evaluation: self-evaluation (Dewey, 1933; McNamara and O'Hara, 2009; Schön, 1983, 1987; Wehmeyer and Field, 2007); and mentoring (Cherian, 2007; McCaughtry et al., 2005; Morton, 2005; Walkington, 2005). The first strategy is self-evaluation (McNamara and O'Hara, 2009) or reflective thinking in Dewey's (1933) and Schön's (1983, 1987) term, or self-determination to use Wehmeyer and Field's (2007) term. Although these authors use different terms, the terms all connote a similar function, which is to give teachers an autonomous space to look into their own practices and provide feedback on their teaching. For Indonesia, this would be a new way of evaluating teaching. Nevertheless, such an evaluation system needs to gain acceptance in the education community (McNamara and O'Hara, 2009) in Indonesia because of its effectiveness. The basic tenet of self-evaluation is a persistent and a careful consideration of previous teaching experience that enables new teaching insights.

Mentoring is another way of helping teachers achieve their best classroom pedagogy. Mentoring came to prominence in the late 1980s and early 1990s when education reformers believed that on-site assistance would help new teachers adjust to their life in teaching (Cherian, 2007). Mentoring is one-on-one assistance between new teachers and their mentors, senior and successful teachers, which is characterised by a close collaboration between the mentorial specialists and the new teachers. Mentors can guide new teachers in their transition time in their new career and can help them implement their curriculum successfully. Mentors can also provide advice on classroom teaching, and give feedback on the classroom practices of new teachers (McCaughtry et al., 2005).

Self-evaluation and mentoring should both find a place in Indonesian schools. Self-evaluation through reflective teaching, for example, can be implemented for Indonesian senior teachers because they are 
assumed to have obtained the ability to evaluate their own teaching, although mentoring may be best utilised for novice teachers who have less teaching experience (Walkington, 2005).

\section{Assessment System Reform}

Teachers are encouraged to use assessment systems that are congruent with their learning goals. They need to provide feedback on students' work to allow their students to learn from mistakes. Bransford, Brown and Cocking (1999) propose two kinds of assessment to be used in schools; formative and summative. Formative assessment is administered in the classroom and provides feedback to improve students' learning; an example might be teachers' comments on their students' work. A good formative assessment is an important component of classroom teaching; such an assessment will improve dialogue between students and teachers, which in turn provides opportunities for students to understand their progress (Carless, 2008). A formative assessment is also important as a guide that leads students to succeed in summative assessments that are administered at the end of a learning period. There is no suggestion that summative assessment should be totally avoided. Summative assessments may be used as the evaluation method to understand learning achievement (Bransford et al., 1999; Carless, 2008). However, such an assessment should be appropriately administered to enable schools to determine student outcomes because summative assessments are sometimes not well integrated with teaching and learning (Carless, 2008, p. 11). This is the case in Indonesian education; the summative examinations, especially the one administered at the end of the school year, the national examination, is not integrated with the process of learning; it is merely with a test of students' memorisation skills (Gardiner, 2005; Lie, 2004).

Understanding the nature of assessment is urgent as a source of teachers' empowerment. Assessments are indeed significant as a guideline to understand learning outcomes (Looney, 2008), and a good form of assessment according to Looney (2008) is a formative 
assessment. Therefore, to avoid rote learning, Indonesian teachers are encouraged to use frequent self-made formative assessments, which do not necessarily test students' memorisation skill. Australian education has implemented a series of teacher-made formative and summative assessments because, through such assessments, teachers are better able to understand their students' progress. In spite of the importance of evaluation as a foundation to understand students' academic progress, misplaced quality control will yield negative implications. In recent times, Indonesian education has been attacked for its failure to design an effective summative assessment; there has been much adverse criticism of the national examination (ujian nasional), which is administered at the end of secondary schooling (Gardiner, 2005; Lie 2004). Indeed, there is merit in the criticisms of the ujian nasional because the examination fails to appropriately define learning success.

Schools in the Australian state of Victoria do not administer a single examination for a summative assessment; they implement a series of assessments throughout the Victorian Certificate of Education (VCE) school years, that is, Years 11 and 12 (grades 2 and 3 in the Indonesian senior high school system). A summative assessment by a single examination is only made in Years 3, 5, 7 and 9 as a source of quality control for the government on school quality. ${ }^{1}$ The series of in-class and external assessments in the VCE give a better picture of students' intellectual ability. Indonesian teachers should understand that learning is a process rather than a product; some students understand a lesson more quickly, others need a longer time to gain in-depth understanding. Therefore, judging students' intellectual quality through a single summative assessment does not generate a valid picture of their intellectual capability. The series of assessments as implemented in Victorian schools should find a place in Indonesian schools. Such full assessments throughout the school years allow teachers to learn students' strengths and weaknesses and also enable students to know their abilities and talents.

1 Personal communication from Rosemary Viete, the international student advisor at the Faculty of Education, Monash University, Australia, in May 2009 
Reforming assessment systems; shifting from rigid summative assessments to a series of formative assessments would help teachers reformulate their classroom pedagogy. Indonesian teaching need no longer be trapped into forcing students to memorise topics of lessons and, best of all, such a reform would allow teachers to implement creative classroom pedagogy.

\section{Attributes of Successful Teachers: Insights for Indonesian Teachers}

In the previous section, I made three suggestions to end the long history of teacher-centred and rote learning. These solutions, however, are not quick-fix prescriptions; they are ideas for improvement that are considered applicable to Indonesia. Now, in the following section of this article, my concern is to provide insights on the attributes of successful teachers. These attributes allow Indonesian teachers to understand those important teachers' qualities that lead to succeed in teaching.

\section{Promoting a Learning Community}

The article suggests that the first attribute of successful teachers is their understanding of their students' attitude to learning because having knowledge of students' learning and the factors that affect their learning attitudes are necessary for effective teaching (Marjoribanks, 1991). Teachers need to look closely at their students' learning styles and explore related factors that influence this: factors such as family background and social status need to be taken into account (Marjoribanks, 1991) because these affect the way students learn. Giddens (2001) suggests that students' social cultures influence their ways of interaction, and also affect their subsequent experience at school. For example, Giddens (2001) states students from poor families use a restricted [language] code to express themselves compared with an elaborated code used by students from affluent families. This is because parents from poor families usually talk to their children in simple and direct language, which influences the way their children express themselves. On the other 
hand, the parents from affluent families will give reasons when talking to children about a particular thing. This elaborated code helps children to develop rational skills, with which they are better able to meet the demands of an academic setting (Giddens, 2001). Giddens' example suggests that social cultures have significant roles in shaping students' attitudes to learning. This indicates that understanding students' ways of learning is an important attribute of successful teachers.

Understanding students' learning styles and the factors that influence this enables teachers to develop the most appropriate ways of interacting with their students in and out of the classroom. They would also be more conscious of their students' social circumstances. For example, when students fail to achieve satisfactory academic results, teachers will first explore factors affecting students' learning attitude without making unwarranted assumptions. In addition to understanding the nature of learning and what influences it, the teacher should also possess sociological and psychological knowledge. Having such knowledge, teachers would be better able assess and treat their students (Marjoribanks, 1991)

Understanding how students' learn is a prerequisite for successful and effective teaching (Marjoribanks, 1991); such understanding allows teachers to teach more effectively. There is a consensus that most Indonesian teachers are uni-disciplinary; they are not prepared with a knowledge of sociology, psychology and communication that would help them shape classroom practices (Buchori, 2001). Acquiring multidisciplinary knowledge is necessary because it allows someone to be a better teacher, a better facilitator and a better educator. Instilling these supporting disciplines should be done through teacher training colleges or through in-service training (Buchori, 2001).

Effective teachers also need to be conscientious about their students' sociological and psychological maturity; successful teachers act as teachers and as educators. As educators, Indonesian teachers may need to transform their perception about the nature of school education. Schools do not function merely as places to instil knowledge; they are moral agents where students' morality and emotional capacity is 
shaped and moulded (Buchori, 2001). Moulding students' morality and emotional maturity can only be achieved through the passion and the commitment of educators. Therefore, as a place to mould students' emotional maturity, Indonesian schools should be transformed into learning communities, or 'community centre' to use Bransford, Brown and Cocking's (1999) term; a place where learning, instruction and cooperation take place.

Bransford et al. (1999) and Donovan and Bransford (2005) assert that effective teachers should transform their schools to be community centred. This kind of environment allows teachers to practise their skills differently. In community-centred schools, teachers and students interact cooperatively as do people living in the community. To make this possible in the Indonesian setting, Indonesian schools, for example, might design a monthly program such as school camps where lateral interaction between teachers and students can be possible. During the school camp, teachers have opportunities to have in-depth exploration of their students' characteristics and social backgrounds.

One other attribute of successful teachers is that they are oriented to democratic teaching. Democratic teaching regards students' mistake as normal in the instructional process. For example, punishing students for an inability to solve a maths problem or for their inability to do homework will discourage students, and hamper their academic improvement. The basic tenet of a democratic classroom according to Wolk (1998) is respecting students because only then can meaningful learning occur. A democratic environment in the classroom will allow teachers to better understand their students' capabilities from any mistakes they might make. In democratic classrooms, collaborative learning is encouraged and student competition is discouraged; competition between students will in fact impede their learning (Wolk, 1998). Watkins, Carnell and Lodge (2007) assert that in collaborative learning, students adjust their behaviour to achieve shared goals. For example, students work in groups to solve a particular problem in their lesson. Therefore, autocratic and unhealthy classroom cultures should be transformed into healthy and democratic learning environments. 


\section{Pedagogical Knowledge}

This article also assumes that successful teachers are qualified in pedagogical knowledge and in effective teaching methods. To teach effectively and successfully, teachers need sufficient pedagogical knowledge. This means that teachers should be able to build an effective learning environment which nurtures students' intelligence (Bransford et al, 1999; Donovan and Bransford, 2005). According to Bransford et al. (1999), one way to improve teaching is to shift from teacher-centred instruction to learner-centred. The latter recognises and appreciates students' presence in the classroom. In learner-centred teaching environments, students come to recognise their own potential talents (Watkins et al. (2007). Teachers adopting a learner-centred teaching style not only understand their subject matter but also position themselves as learners so they can be more understanding of students' social background (McCombs, 2007). The most important of all is that, according to Shor (1992), learner-centred classes allow democratic dialogue. Such dialogue is significant in the attempt to create a healthy learning environment because it gives students the space to voice their understanding or point of view on issues. Shared authority in the classroom will allow critical dialogue to emerge. In spite of the importance of dialogue in the classroom, Shor (1999) acknowledges that most teachers will resist such an idea.

In addition to learner-centred instruction, Bransford et al. (1999) and Donovan and Bransford (2005) argue that successful teachers should transform their school into a knowledge-centred environment. In their classroom pedagogy, effective teachers connect their understanding of students with the new information they are about to teach. In this case, students' expression of opinion is encouraged (Fraser, 2005). Fraser (2005) also suggests that effective teachers teach subjects in depth, covering fewer topics in one session or class rather than teaching wider topics superficially. Indonesian teachers should be informed regarding this effective teaching style because they still expect students to study a great many subjects extensively. In addition, to succeed in teaching, teachers need to understand pedagogical content knowledge (PCK). PCK 
is an in-depth understanding of the content knowledge of the subject and the methods of teaching that content knowledge, as distinct from pedagogical knowledge discussed earlier. The notion of PCK is rooted in the belief that teaching is more than transferring the content knowledge to students (Loughran, Berry and Mulhall, 2006). The basic tenet of PCK is that teachers develop their knowledge of subjects over time and also learn how to pass on this knowledge effectively. The combination of teachers' understanding of content knowledge and pedagogical knowledge will allow professional learning to occur (Loughran et al., 2006). Developing PCK is expected to be able to help resolve the problem of Indonesian teachers' classroom pedagogy. In the attempt to transform Indonesian teachers in accordance with the mandate of PCK, teacher training should aim at teacher's content knowledge and at their pedagogical knowledge. The prajabatan training, therefore, should play this role instead of being used to merely instil civic education as it is currently practised.

\section{Discussion}

\section{Making Sense of the Proposed Solutions}

In this section, I attempt to link the two factors that cause teacher-centred and rote-learning to continue in Indonesian schools to the solutions provided. Systems played out within the civil service institutions and the school cultures are assumed to contribute to teacher-centred traditions. Teachers are subject to the civil service disciplinary regulations (Bjork, 2005; Gardiner, 2000) because they are recruited and governed on the authority of the central government (Gardiner, 2000). In response to this fact, Shor (1992) suggests that the way schools are governed is political; the design of curriculum is not negotiated with teachers; and school practices are mandated by the school authority, which leaves little space for teachers to be creative in their teaching. This statement is very true in the Indonesian education context. Bjork (2005) illustrates how Indonesian teachers are influenced by various elements; there is the influence of the state, of parents, of the students and the teachers are also governed by their own values on education (Bjork, 2005, 
p. 162). For those reasons, it is imperative that teachers should be detached from the civil service system. If this is done then reform of teacher recruitment will follow. Decentralising teacher recruitment is assumed important in the attempt to recruit professional teachers. In making decentralisation of teacher recruitment possible, the Ministry of Religious Affairs and the Ministry of National Education should be willing to share power with local school committees. In fact, the two ministries should cooperate to help the schools running the tests by supplying facilities and staff that can help schools administer the test. In this case, candidates for teaching positions would be expected to apply directly to the school they wish to teach at. The school board or committee would then select the candidates after carefully considering their formal and other qualifications and then arrange for a written examination and a practicum test. If this procedure is employed, schools will be better able to select from the best possible candidates and have more control over their teachers' classroom practices.

Having been given authority to recruit teachers, schools would have greater autonomy to design recruitment tests, the procedure for the tests and the areas to be tested. To teach successfully, teachers need to acquire necessary teaching skills or pedagogical knowledge. In addition, teacher candidates should also acquire in-depth knowledge of the subject matter or the content of the subject. The areas of testing should be in the specific areas to which teacher candidates apply. For example, in recruiting English teachers, schools should employ tests that evaluate knowledge of the English language (content knowledge) and teaching skills (pedagogical knowledge). In evaluating content knowledge, the school could design various examinations that test all the skills necessary for teaching English; and to gauge a candidate's teaching skills, the school could use practicum as a means of evaluation (Belliveau, 2007). The pegawai negeri institutions (the Ministry of National Education and the Ministry of Religious Affairs), which assess subject knowledge, have failed to recruit properly qualified teachers because their testing neglects the prerequisites for a good teacher, that is, pedagogical ability. Because basic pedagogical ability of teachers is neglected in their recruitment, most Indonesian teachers lack teaching 
competence, which results in poor student academic achievement.

The other test that is also considered important is testing of emotional maturity by which teacher candidates' emotional quotient can be identified. This suggestion might be inapplicable in the Indonesian setting unless the Ministry of Religious Affairs and Ministry of National Education delegate authority to their provincial branches. Decentralising authority is not common in Indonesia though there have been efforts to do so (Bjork, 2005).

Decentralising teacher recruitment is difficult but not impossible. Christopher Bjork during his research observes that the central government is not very committed to decentralisation. Bjork (2005, p. 171) contends 'if the government is indeed committed to decentralisation, it is imperative that more attention is paid to the implications for local agencies and actors'. This quote suggests some of the difficulties of decentralisation of teachers' recruitment. In another instance, Bjork (2005, p. 172) asserts ' ...the MOEC ${ }^{2}$ is now asking them [Indonesian teachers] to act autonomously - to shape policy and practice at schools', and 'Indonesian teachers may voice their support for decentralising control of the curriculum and claim to have modified their practice... but their actions rarely match their word' (Bjork, 2005, p. 173-174). The last two quotes clarify that what makes decentralisation of teachers' recruitment difficult is, on the one hand, that the government is not very committed to transferring authority to local schools and education practitioners (Gardiner, 2000); and, on the other, that local schools and teachers themselves lack the capability to accommodate to decentralisation. This effort, however, is not impossible as long as the central government is committed to decentralisation and provides full support during the transition period. The key point to the success of decentralisation of teacher recruitment is the government's discretion to commit and support the decentralisation process.

This article also provides two other ways of evaluating teachers: selfevaluation and mentoring. The notion of self-evaluation has yet to a place

2 Ministry of Education and Culture (MOEC) now replaced to Ministry of National Education (MONE) 
in the Indonesian school setting. In self-evaluation, teachers rely on their own commitment to evaluate their teaching to enable them improve their classroom pedagogy. One popular strategy that Indonesian teachers can engage in self-evaluation is through reflective teaching. Engaging in reflective teaching enables teachers to think and learn about their own teaching and then allows them to make a decision on how to improve their teaching (Kreber and Cranto, 2000; Rogers, 2001). Teachers may engage in reflective teaching through various methods: video recording, collaborative teaching, and journaling (York-Barr, Sommers, Ghere and Montie, 2006). All three methods of reflective teaching have strengths and weaknesses. The advantage of the video recording is that it enables teachers to watch their own teaching. By watching their teaching style in video cassettes, teachers will be better able to examine and provide feedbacks about their teaching. ${ }^{3}$ However, the drawback of this method is apparent in the Indonesian school settings. Reflection through video recording requires a fully equipped teaching laboratory; such facilities are absent from most Indonesian schools.

The second method of reflection is collaborative teaching. This is a very effective way to reflect on teaching; collaborating in examining one's teaching will yield better results than individual reflection (YorkBarr et al., 2006) This method is promising in the Indonesian context because it is not very costly and it can be realised through careful selection of colleagues who are willing to collaborate in their teaching. However, this method also has a weakness; most Indonesian teachers feel reluctant to criticise their colleagues and are not very comfortable accepting criticism from them. If this is so, improving teaching through collaborative learning will not give an effective result because the basic tenet of collaborative teaching is in sincere and constructive criticism of colleagues' teaching (Dewey, 1933).

Writing journal, the third method, makes 'invisible thoughts visible'

3 The benefits of video recording as a method of reflective teaching have been proven during my practicum program at Ohio University. In the practicum, I was obliged to video-tape my own teaching and reflect on it. By watching my own teaching, I could identify my teaching styles and reflect on their strengths and weaknesses. My reflection through video recording allows me to understand my own teaching and make some improvement. 
(York-Barr et al., 2006, p. 87) because it helps teachers to criticise, praise and evaluate their teaching individually in a written form. ${ }^{4}$ In addition, such a technique seems to be applicable in Indonesian settings. By using a journal, teachers can write about any issues concerning their own teaching. The strength of this method is in its confidentiality; it remains personal - only the owners of the journal have access to what has been written. However, writing a journal has yet to become a custom in Indonesian school teaching; teachers are not very keen to do this. Writing a journal takes much time and it needs a great effort to produce even a single journal. In spite of weaknesses of these three introspective methods, they are worth trying to help improve teachers' classroom pedagogy. To encourage reflective teaching, Indonesian schools should provide space, opportunities and encouragements to enable this.

The second method of teacher evaluation is through mentoring. Indonesian schools should consider implementing a mentorial system, and make it a part of the school system. Improving teachers' classroom pedagogy through mentoring is popular because it has been implemented elsewhere in the schooling system. School principals, superintendents and successful, experienced teachers play major roles in making mentoring possible in Indonesian schools. Successful principals are those who are concerned with their staff's development, in which they engage in intellectual stimulation, and in modelling important values and practices (Raihani, 2008). With mentoring, for example, senior teachers are appointed to mentor their juniors (McCaughtry et al., 2005). Mentoring is important in the educational settings because it allows junior teachers to learn from their senior colleagues. However, in Indonesia, junior teachers might well have obtained a higher degree than that of the senior teachers; this difference of degree status can cause resistance to the mentors from those who are mentored.

Although some issues may arise in the implementation of self-evaluation

4 The findings of my research conducted at Ohio University in 2005-06 indicate that inservice teachers find journaling beneficial to improve their teaching. Even though they realize that writing journal is difficult in their hectic schedule, being committed to writing a journal about one's teaching will generate greater benefits that may boost their teaching confidence. 
and mentorial systems, these teacher evaluation systems should have a place in Indonesian schools.

Self-evaluation should be instilled through a series of pre- and inservice teacher training. The mentorial program may be applicable through careful management from the schools and also the Ministry of Education. In this case, the MONE and MORA may assign senior and experienced teachers from other schools to a particular school. By so doing, the assigned mentors will gain respect from those who are receiving help and advice. The other solution is that the experienced and respected teachers in a particular school should be assigned as specialist mentors. This strategy is expected to eliminate resistance that may arise when a mentorial program is run.

The third proposed solution is to reform the assessment system. Tan and Towndrow (2009) contend that there is agreement on the link between assessment and learning achievement. Assessment is indeed a powerful way to understand students' learning achievement. However, discrepancies occur when discussing the best types of assessment to administer. This article suggests that there are criticisms of the current Indonesian system of academic assessment (Daud, 2009; Khalifa, 2009; Soaloon, 2009) and that a series of formative assessments be used as system of measurement instead of summative assessment. The formative assessment is significant because it is frequently used to assess learner understanding and academic progress and can be used as a foundation to identify needs and shape teaching (Looney, 2008). Such an assessment is also known as assessment for learning, distinct from assessment of learning, which refers to the summative assessment (Looney, 2008, p. 22). This indicates that implementing formative assessment yields two benefits: it improves teachers' awareness of effective classroom pedagogy; and it also provides insights to students' academic achievement.

In spite of this wonderful system of assessment (the formative assessment), reforming the system of school assessment is complex and challenging, but it is not impossible if the central government intends to review methods of assessment constantly and is committed to listening 
to criticisms of the current system. Simply to say, to solve the problem, that the central government should only administer centralised national assessment in the Year 11 (grade 2 of SMU in the Indonesian system). This centralised national examination cannot be used as an indicator of students' academic achievement; in fact, this examination becomes the barometer and guideline for the government to measure school quality. This national assessment should have two purposes: to assess the school and also to assess students' academic progress. In the upper grade, Year 12 (grade 3), schools are authorised to administer a series of in-class formative assessments to identify students' progress. If the summative assessment, such as the national examination (ujian nasional) can be altered and shifted, rote learning can be abolished in Indonesian schools. This reform, however, can be made only through central government commitment and the positive response of the local school committees.

\section{Empowering Indonesian Teachers}

The article suggests some emergent attributes of effective teachers: first, effective teachers need to promote a learning community; and second, successful teachers must acquire pedagogical and content knowledge. In the attempt to promote a learning community, the article suggests that effective teachers understand the nature of learning, how students learn and the factors influencing their learning. Successful teachers also acquire multi-disciplinary knowledge that helps them understand their students better; and they employ democratic instruction practices. The two effective classroom pedagogies are teacher-centred and knowledge centred. These proposed solutions are indeed promising. However, whether these solutions are applicable and can be easily implemented in Indonesian schools needs further analysis. One way to make this solution applicable in Indonesian schools is by preparing teachers with multi-disciplinary skills during their pre-service training as student teachers. For example, faculties of education should offer subjects on the nature of learning, educational psychology, educational sociology and communication skills. These subjects actually have been offered in the curricula of teacher colleges; however, they are not integrated with 
teachers' classroom pedagogy. Student teachers are not informed about how to integrate such subjects with their classroom practices upon entering a real teaching career. As a result, student teachers only sit these subjects for the sake of getting a passing score. Because instilling multi-disciplinary skills into the curriculum of a faculty of education is considered insufficient, the other strategy that might be considered is through in-service teacher training. During in-service teacher training, the school and the government body should make an attempt to prepare teachers with multi-disciplinary skills.

\section{Closing Remarks}

This article has considered problems of Indonesian education in general and in particular problems associated with Indonesian teachers. The article identifies that Indonesian teachers are employing teacher-centred teaching approach and rote learning as the instructional method. The long history of teacher-centred and rote learning in Indonesian schools is because of the influence of institutional cultures and the assessment system employed in the education system. To minimise the use of teacher-centred and rote learning, the article suggests that educational policymakers in Indonesia alter the recruitment system; reformulate teaching evaluation; and reform assessment systems. These three solutions are expected to be able to improve teachers' instructional methods, in which the use of teacher-centred approach and rote learning system can be minimised. This article also provides attributes of successful teachers in a special section of discussion. The section aims at giving insights to Indonesian teachers, policymakers and school practitioners on characteristics of successful teachers.

\section{References}

\section{Books and Journals}

Azra, A (2002). Paradigma Baru Pendidikan Nasional: Rekonstruksi dan Demokrasi. Jakarta: Kompas.

Belliveau, G (2007). An Alternative Practicum Model for Teaching and Learning. 
Canadian Journal of Education, 30 (1), 47-67.

Bjork, C (2005). Indonesian Education: Teachers, Schools, and Central Bureaucracy. New York and London: Routledge.

Bransford, JD, Brown, AL, and Cocking, RR (eds) (1999). How People Learn: Brain, Mind, Experience, and School. Washington, DC: National Academies Press.

Buchori, M (2001). Notes on Education in Indonesia. Jakarta: Jakarta Post and Asia Foundation.

Carless, D (2008). 'Developing Productive Synergies between Formative and Summative Assessment Processes'. In M-F Hui and DL Grossman (eds), Improving Teacher Education through Action Research. New York: Routledge.

Cherian, F (2007). Learning to Teach: Teacher Candidates Reflect on the Relational, Conceptual, and Contextual Influences of Responsive Mentorship. Canadian Journal of Education, 30 (1), 25-46.

Darmaningtyas (2004). Pendidikan yang Memiskinkan. Yogyakarta: Galang Press.

Dewey, J (1933). How we Think. New York: DC Heath.

Donovan, MS, and Bransford, JD (eds). (2001). How Students Learn: History,

Mathematics, and Science in the Classroom. Washington, DC: National Academies Press.

Fraser, D (2005). Professional Learning in Effective Schools: the Seven Principles of Highly Effective Professional Learning. Melbourne: Department of Education \& Training.

Giddens, A (2001). Sociology (4th edn). Cambridge: Polity Press.

Ingvarson, L and Chadbourne, R (eds). (1994). Valuing Teachers' Work: New

Directions in Teacher Appraisal. Melbourne: Australian Council for Educational Research.

Kreber, C and Cranton, PA (2000). 'Exploring the Scholarship of Teaching'. The Journal of Higher Education. 71 (4): 476-495.

Kohl, H(1992). 'Iwon'tlearn from you'and Other Thoughts on Creative Maladjustment. New York: The New Press.

Looney, J (2008). Teaching, Learning and Assessment for Adults: Improving Foundation Skills. Paris: OECD.

Loughran, J, Berry, A, and Mulhall, P (2006). Understanding and Developing Science Teachers'Pedagogical Content Knowledge. Rotterdam: Sense Publishers.

Marjoribanks, K (ed.). (1991). The Foundations of Students'Learning. Oxford, New York: Pergamon Press.

McCaughtry, N, Kulinna, PH, Cothran, D, Martin, J, and Faust, R (2005). Teachers Mentoring Teachers: a View over Time. Journal of Teaching in Physical Education, 24, 326-343.

McCombs, BL, and Miller, L (2007). Learner-centered Classroom Practices and Assessments: Maximizing Student Motivation, Learning and Achievement. Thousand Oaks: Corwin Press.

McLaughlin, MW, and Pfeifer, RS (1988). Teacher Evaluation: Improvement, Accountability and Effective Learning. New York: Teachers College Press.

McNamara, G, and O'Hara, J (2009). Trusting Schools and Teachers: Developing 
Educational Professionalism through Self-evaluation. New York: Peter Lang. Morton, ML (2005). Practicing Praxis: Mentoring Teachers in a Low-income School through Collaborative Action Research and Transformative Pedagogy. Mentoring and Tutoring, 13 (1), 53-72.

Raihani. (2008). An Indonesian Model of Successful School Leadership. Journal of Educational Administration, 46 (4), 481-496.

Rogers, RR (2001). 'Reflection in Higher Education: a Concept Analysis'. Innovative Higher Education 26 (1): 37-57.

Schön, DA (1983). The Reflective Practitioner: How Professionals Think in Action. New York: Basic Books.

Schön, DA (1987). Educating the Reflective Practitioner: Toward a New Design for Teaching and Learning in the Professions. San Francisco and London: JosseyBass Publishers.

Shor, I (1992). Empowering Education: Critical Teaching for Social Change. Chicago and London: University of Chicago Press.

Tan, AL, and Towndrow, PA (2009). 'Catalyzing Student-Teacher Interactions and Teacher Learning in Science Practical Formative Assessment with Digital Video Technology'. Teaching and Teacher Education, 25, 61-67.

Walkington, J (2005). Mentoring Preservice Teachers in the Preschool Setting: Perceptions of the Role. Australian Journal of Early Childhood, 30 (1), 2835.

Watkins, C, Carnell, E, and Lodge, C (2007). Effective Learning in Classrooms. Thousand Oaks: Paul Chapman Publishing.

Wehmeyer, ML, and Field, SL (2007). Self-determination: Instructional and Assessment Strategies. Thousand Oaks: Corwin Press.

Wolk, S (1998). A Democratic Classroom. Portsmouth: Heinemann.

York-Barr, J, Sommers, WA, Ghere, GS, and Montie, J (2006). Reflective Practice to Improve Schools: an Action Guide for Educators (2nd edn). Thousand Oaks: Corwin Press.

\section{Websites}

Daud, ZBM (2009). Mempertanyakan efesiensi UN. Retrieved 1-05-2009, 2009, from http://id.acehinstitue.org

Khalifa, S (2009). UN, formalitas nasional yang irrasional. Retrieved 1-05-2009, 2009, from http://id.acehinstitute.org

Lie, A (2004). Tujuan akhir nasional: kesenjangan kekuasaan dan tanggung jawab. Retrieved 15-09-2009, 2009, from http://www.komunitasdemokrasi.or.id

Oey-Gardiner, M (2005). Ujian Nasional: Mengukur standar mutu atau 'UUD'? Retrieved 15-09-2009, 2009, from http://www.ihssrc.com

Soaloon, BT (2009). Dusta ujian nasional. Retrieved 23-04-2009, 2009, from http:// id.acehinstitute.org 


\section{Personal Communication}

Rosemary Viete (international student advisor) at the Faculty of Education, Monash University, April 2009 